\title{
Charting a New Path for Poland or Turning Its Back On More Than a Quarter Century of Progress?
}

\author{
Richard J. Hunter, Jr. \\ Professor of Legal Studies \\ Seton Hall University
}

\begin{abstract}
The paper analyzes the Morawiecki Plan for the Polish economy in light of its emphasis on encouraging domestic, rather than foreign, development in Poland. It discusses the critique of the current government relating to foreign ownership of assets in Poland and what the government intends to do about reversing this trend from both historical and practical perspectives. The paper includes both positive and negative assessments of these proposed changes in policy and emphasis.
\end{abstract}

KEYWORDS: Balcerowicz Plan; Foreign Direct Investment; Incentives; Morawiecki Plan

\section{INTRODUCTION}

From the perspective of nearly twenty-eight years, it is now possible to state with certainty that despite a "propaganda of success" trumpeted by adherents to the former system of central planning (also called the command-rationing method or CRM), the economy of Poland had literally imploded by 1988-1989 because of a combination of four interrelated factors, which Hunter and Ryan (2006) have termed the "Grand Failures" of the communist system as it existed in Poland. These factors included:

- Failure to create economic value or to improve the standard of living for the average Pole;

- Failure to provide adequate individual and organizational incentives;

- Failure to "measure up" to comparative economies, not only those capitalist economies in the West, but also several "fraternal" socialist economies in Central and Eastern Europe (most notably, Hungary, Czechoslovakia, and Slovenia-then a part of Yugoslavia); and

- Failure to satisfy basic consumer needs, essentially creating an unofficial dollarization of the Polish economy through the existence of a large, open, semi-official, and surprisingly efficient black market, and the existence of official "dollar" stores and foreign currency shops. (Adapted from Hunter \& Ryan, 2006, p. 73).

Since transitioning from communism in 1989, Poland's young, skilled, and low-cost workforce, coupled with political stability and business-friendly policies, has appealed to an array of foreign investors. The initial changes in the Polish economy which created an investor friendly atmosphere were largely accomplished under the aegis of the Balcerowicz Plan (Garland, 2015)—named for the Deputy Prime Minister and Minister of Finance in the first postcommunist government led by Prime Minister Tadeusz Mazowiecki. (Sachs, 1993a; Hunter \& Ryan, 2009). 


\section{The Balcerowicz Plan}

Early in the transformation process, Minister Balcerowicz and team of advisors, led by American economist Jeffrey Sachs, decided on a reform strategy that would be based on two overriding considerations: A market economy was preferred over a centrally planned economy and a private market economy was preferred over so-called "market socialism." In addition, Minister Balcerowicz decided upon a policy of implementation termed "shock therapy" where political and economic changes would be effected in a short period of time. (Murrell, 2013).

As result, the largely successful process of economic transformation in Poland has been quite instructive and has provided a more general model for other "transition economies" - although it has not escaped criticisms which have argued that the program has favored "foreign" over "Polish" national interests.

The program conceived by Minister Balcerowicz was based on what are known as the "five pillars of economic transformation." These included:

1. Rapid transformation of the failed monocentric system of state central planning (Kaminski, 1991) into a private functioning market economy;

2. Liberalization of economic functions, especially in relation to foreign trade and foreign direct investment;

3. Privatization of state-owned enterprises (SOEs) (Sachs, 1993b);

4. Construction of an effective social safety net; and

5. Mobilization of international financial assistance (especially from the World Bank and the International Monetary Fund) to support the process. (Generally Balcerowicz, 1995; Hunter \& Ryan, 2008; Hunter \& Ryan, 2009).

As noted by Johnson and Loveman (1995) in the Harvard Business Review, the program was intended to:

"... stabilize the macroeconomy and to create the conditions necessary for privatization, enterprise restructuring, and the development of an institutional system compatible with a market economy. Because of the speed and scope of the reforms, the impact on Polish markets and enterprises was immediate and profound. Remarkably, the main goals of the program, widely known as "shock therapy," were achieved within a few months."

\section{THE RESULTS}

It is undoubtedly true that Poland's economy has seen tremendous growth over the past 25 years - much higher than anyone could have imagined. While the European Union's average growth rate has been .6\% since 2007, Poland's economy grew an impressive 24\%. (United States Department of State, 2015). Poland was the only EU nation that managed to avoid a recession (and actually continued to grow) during the 2008-2009 financial crisis despite surrounding neighbors' tanking economies. (Generally, Orenstein, 2014).

The following are selected economic data relating to the current economic situation in Poland:

Population of Poland

GDP Growth (Constant Prices, National Currency)

GDP (Current Prices, US Dollars)

GDP Per Capita (Current Prices, US Dollars)

GDP (PPP) (US Dollars)
$38,630,868(01 / 16 / 2017)$

$3.571 \%$

$\$ 473.501$ Billion

$\$ 12,459.59$

$\$ 1,051.56$ Billion 
Inflation (Average Consumer Price Change \%)

Unemployment rate (\% of the Labor Force)

Industrial Production

Stock Market

Public Debt as a \% of GDP

Trade Balance (Euro)
-.238 to -.05

$8.2 \%$ to $8.6 \%$

$4.8 \%$

$-9.6 \%$

$51.3 \%$

2.1 Billion

(FocusEconomics, 2017).

But do these figures tell the whole truth? Skeptics contend that the unemployment rate is not completely accurate, as 850,000 Poles (mainly youth) are living and working in the United Kingdom and more than 1.15 million additional Poles are living and working throughout the European Union, skewing the real rate of unemployment. (Burrell, 2009/2016).

In addition, many observers point out that there have been grave negative consequences for Polish society. The 2015 Corruption Perceptions Index ranked Poland 30/168 and gave it a score of $62 / 100$ (the closer the score is to 100 the cleaner and less corrupt the country is). (Transparency International, 2016). The majority of corruption occurs in the public services and public procurement sectors. As Business Anti-Corruption reported: "Poland's Criminal Code offenses include active and passive bribery of foreign officials, extortion and money laundering. However, the government does not prosecute these offenses effectively, and officials engage in corruption with impunity." (Business Anti-Corruption, 2016). The Poland Country Profile further notes that despite "facilitation payments and gifts being criminalized, these practices are widespread." (Business Anti-Corruption, 2016). (Generally Hunter \& Mest, 2015; Hunter and Domanska, 2016).

Corruption and bribery were perceived by many Polish voters as unacceptable results of the transition that could have been anticipated because of the manner in which successive Polish governments, following the general outlines of the Balcerowicz Plan, had conducted "business as usual” to the detriment of the average Pole. (Generally, Heywood \& Meyer-Sahling, 2013).

\section{ATTRACTING FOREIGN DIRECT INVESTMENT}

For countries with depressed or non-functioning economies, little capital, and high unemployment rates such a Poland, Foreign Direct Investment (FDI) was seen as the literal "economic savior" and an attempt to answer a fundamental question: How do you create capitalism in a country where you can find neither capital nor capitalists? The answer, of course, was to attract foreign capital, foreign investors, and foreign ownership into Poland. That perspective became the guiding objective of much of Poland's economic planning, as well as sparking changes in the Polish legal system that made it possible for "foreigners" to become owners of Polish enterprises, real property, and businesses. (Hunter, Nowak \& Ryan, 1995).

FDI can be a mutually beneficial way of stimulating the economy and job market in a recipient nation, often by carefully targeting select economic sectors. (Hunter \& Ryan, 2013). FDI encourages the inflow of new technology, products, capital, and potential opportunities and for collaboration with local businesses that would otherwise not be possible. Heimann (2001, pp. 8-11) is even more direct in a seminal study of tax incentives relating to foreign direct investment in Poland. She stressed the importance of Foreign Direct Investment in Poland and noted that foreign capital can facilitate the restructuring of industry through:

- Attraction of incremental investment capital,

- Enhanced access to Western markets, 
- Access to advanced management techniques,

- Access to advanced management techniques,

- Access to advanced technologies, which stimulates technological adaptation and innovation and that leads to faster economic growth, and

- Facilitation of privatization and restructuring of the economy.

Poland's track record in terms of attracting FDI has been, in fact, quite impressive. (Jasiniak, 2015). The Polish Information and Foreign Investment Agency (PAIiIZ) reported that the aggregate of FDI had reached 159 billion euro at the end of 2015. Those who invested in Poland were especially drawn to the aerospace, automotive, biotechnology, business support services, domestic appliances, electronics, food processing, IT, renewable energy, and research and development sectors (PAIiIZ, 2016). The manufacturing sector (37\%) and financial intermediation $(25.3 \%)$ attracted well over $60 \%$ of FDI into Poland.

According to PAIiIZ (2016):

- The pool of foreign investors in Poland amounted to 26,464 firms.

- Among new firms created in 2014 there were 1,104 new greenfield projects.

- The great share of investments was in activities related to education (9.2\%), in culture, entertainment and recreation (7.7\%), and in information and communication $(6.0 \%)$.

- Foreign capital in companies where its value exceeded \$1 million in aggregate amounted to $96.5 \%$ of foreign capital invested in Poland.

- Foreign capital located in Poland in 2014 originated from 125 countries. European Union and the OECD countries originated $89.7 \%$ and $93.9 \%$ of foreign capital respectively.

- At the end of 2014 there were 1,748.700 persons employed in companies with foreign capital-fully $7.3 \%$ more than in the previous year. These perspns were employed mainly in manufacturing (45.8\% of all employed) and trade and repair of cars $(23.3 \%)$.

In terms of FDI inflows by country of origin, a list of the main countries who invested in Poland in 2014 included:

- Germany (17.1\%);

- Netherlands (16.1\%);

- France $(11.9 \%)$;

- Luxembourg (9.6\%);

- $\operatorname{Spain}(6.5 \%)$;

- Italy (5.8\%);

- USA (4.3\%);

- Austria (4.0\%); and

- Cyprus (3.8\%).

(OECD, 2014).

Santander Trade (2016) reported that the "strong points" for investing in Poland included:

"A fast-growing economy, a location in central Europe, a multilingual and skilled workforce whose productivity is rising rapidly and cheap labor costs make Poland an internationally attractive country. Poland also enjoys a well-managed economy, which was able to withstand the crisis better than other European countries. Unlike other Central European countries, its population did not have to resort to loans in foreign countries, in particular Swiss loans, a fact which has protected the population from maximum debt." (Santandertrade.com, 2016).

\section{Have All of the Results Relating to FDI Been Positive For Poland?}

From 1989 through 2015, successive Polish governments "more or less" followed policies which tracked the basic philosophy that Minister Balcerowicz had laid down in the early days of the transition. However, a fundamental change occurred with the Presidential and 
Parliamentary elections which took place in 2015. Criticisms were raised relating to several of the fundamental assumptions of the transition itself that related to the participation of foreigners and foreign capital in the Polish economy.

The Sarmatian Review (2016) encapsulated many of these criticisms and reported the following negative aspects of foreign investment in Poland:

- The percentage of factories engaged in manufacturing in Poland owned by foreign entities in 2016 reached more than 50\%;

- More than $60 \%$ of Poland's banks were at one time foreign owned-although the ratio is now nearer to $50 / 50$;

- 90 billion zlotys (or about 25 billion dollars) are transferred from Poland "abroad" each year because of the structure of ownership of Polish enterprises.

There are several other negatives as well. (Connectusfund, 2015). Critics argue that one of the main reasons Poland had experienced so much growth in the private sector through FDI could be attributed to the tax incentives associated with FDI offered by successive Polish governments. In addition to generous tax exemptions and grants, the Corporate Income Tax (CIT) rate was reduced from $40 \%$ in 1991 to $19 \%$ in 2004 and was further reduced to $15 \%$ for small businesses in 2016. (Trading Economics, 2016; Zygulski, 2017). These incentives offered to foreign investors ironically removed much needed revenues from the domestic economy that would be necessary to affect reforms and assure the viability of Poland's troubled and underfunded social safety net. (BMI Research, 2017).

\section{Enter the PiS}

With this backdrop, the new Polish government, now under the direction of Law and Justice (PiS), which gained control of both the Polish Presidency and Parliament in 2015, launched a program specifically designed to "regain control and revitalize the country's economy which has long been plagued by foreign domination...." (Strybel, 2017, p. 2).

PiS has long held that the changes that had occurred in Poland since 1989, and most especially those carried out under the Balcerowicz Plan, had done little to return economic sovereignty to Poland following 123 years of foreign Partition, a difficult interwar period, and nearly 45 years of "communist misrule and mismanagement." (Strybel, 2017).

The criticism was direct and pointed. Instead of concentrating on rebuilding Poland's economic base from within by restructuring and revitalizing Poland's industrial base, the PiS argued that successive Polish governments in the twenty five years after 1989 essentially engaged in a program of selling off important Polish assets-often for a quick infusion of cash which was used to bolster Poland's budget. (Strybel, 2017). This strategy was accomplished in a process known as privatization, which along with economic stabilization, were the two cornerstones of Poland's economic policies begun in 1989. (Jermakowicz, 2001).

Critics argued that the initial push towards removing state control of the economy, now known derisively as "spontaneous privatization," was often no more than the theft of public assets, accomplished through "crony capitalism," as well as clear incidents of insider trading, which favored members of the former nomenklatura, Poland's discredited communist bureaucratic class. (Hunter \& Ryan, 1998, p. 112).

Critics also pointed out that in the past quarter century, some of Poland former "banner" stateowned-industries (or SOEs) such as mines, Baltic ship building facilities (the former Lenin Ship 
Yard in Gdansk, for example), steel making facilities (Nowa Huta) were closed or employment significantly scaled back when the government failed to directly intervene in their deteriorating finances or was unable to procure a foreign buyer willing to invest the sums necessary to modernize operations in order to assure that the businesses would remain open. As a result, tens of thousands of Polish workers became permanently unemployed. At the same time, the economy became dominated by foreign-owned banks, retail giants, and assembly plants controlled by foreigners, which in turn funneled most of their profits abroad to the benefit of foreign investors.

Robert Strybel (2017, writing in the Polish American Journal, provided several examples which include Wyborowa (vodka/owned by Pernod/France), Zywiec (beer/owned by Heineken/The Netherlands), Okocim (beer/owned by Carlsberg/Denmark), Wedel (confectionary and chocolates/owned by Lotte Group/Korea), Pudliszki (food stuffs, tomato ketchup/owned by Kraft-Heinz, US/multinational), Amino (food products/soups/owned by Unilever/British/Dutch) and Winiary (food processing/owned by Nestle/Switzerland). The last Polish car make, the Polonez hatchback, disappeared in 2002. Most surprisingly (and perhaps disappointingly), Krakus brand canned hams (exports of which were the major source of cash into the Polish economy in the 1960's through the 1980's) is now owned by China's WH group, the world's largest producer of pork.

The PiS critique is both philosophical and practical. On policy grounds, PiS is strongly opposed to what it calls Poland's current "neocolonial status" which offers foreign companies a comparative advantage through cheap manpower, lower labor costs than Western European economies, and low cost assembly plant sites-many heavily subsidized indirectly through tax abatements and concessions, entry concessions, R\&D Grants, and other short term incentivesall at the expense of Polish society. (U.S. Department of State, 2013).

\section{The Morawiecki Plan}

The new strategy is embodied in the Morawiecki Plan, named for Deputy Prime Minister Mateusz Morawiecki. It represents sharp and concerted departure from the approach of the Balcerowicz Plan. In a pointed critique of the free market liberalism that has guided Poland since its movement away from its central planning past, Morawiecki noted: "We have been in this [economic] model for 27 years. We have reached the trap of dependent development. To a huge extent we are dependent on foreigners." (Foy, 2016).

Interestingly, Morawiecki is no stranger to issues relating to foreign ownership of Polish assets. Morawiecki resigned as CEO of a Polish subsidiary of a Spanish-owned bank (Santander) where he had worked for eight years in order to accept the position the leader of both development and finance in the government. Morawiecki has assumed responsibility for industrial development, the budget, the continued infusion of European Union funds, and overall economic policy-holding positions of responsibility not seen since those exercised by Minister Balcerowicz in the initial period of transformation.

Morawiecki has made it clear that is not a believer in Polish autarchy or in isolating Poland from foreign investors. However, he has indicated his preference for attracting foreign investors who will bring with their cash investments advanced industrial technologies so that Poland is not regarded, as many do China, as the home of a "dollar shop" manufactured goods.

The key objective of the Morawiecki Plan is to boost Poland's internal investment rate to 25 per cent of GDP. The strategy is based upon alleviating "risks" to long-range growth which the government has identified as "falling into the middle income trap, lack of balance (excessive 
foreign involvement in the Polish economy), insufficient investment of businesses, unfavorable demographic trends and weak institutions (low VAT and CIT collection rates, lack of coordination of public policies." (Borowski \& Jaworski, 2016).

These risks are to be resolved through activities described as Morawiecki's "five pillars of economic development of Poland":

- "Reindustrialization - i.e. focusing on industries in which Poland can gain competitive advantage and attract foreign investment.

- Development of innovative companies, which involves, among others, drawing up a Business Constitution to simplify regulations, helping develop and launch innovative products, and higher spending on research and development.

- Capital for development - aiming for a significant increase in capital expenditure, and an improved efficiency of institutions supporting investment; the establishment of the Polish Development Fund.

- Foreign expansion - support for Polish exports aimed at new markets, conducting foreign trade missions and developing a network of economic diplomacy posts.

- Social and regional development - a proposal of a comprehensive demographic program, the reform of the education system and support for the development of Polish regions." (Borowski \& Jaworski, 2016).

As described by Borowski and Jaworski (2016), the plan delineates several policy objectives to be met by the year 2020. These include an increase in both industrial output and Polish exports at a faster pace than expected GDP growth; a rise in spending for Research and Development activities to 2 per cent of GDP; a reduction in the current at-risk-of-poverty rate below 15.5 per cent of the population; and an increase in per capita GDP to 79 per cent of the EU average by that date as well. In the assessment of Borowski and Jaworski (2016), "the key objective of the program is to raise the investment rate (capital expenditure in relation to GDP) to 25 per cent from the 20 per cent observed in 2015."

The government has stated it would set aside 1 trillion zlotys ( $\$ 252.58$ billion) available to boost investments, "a figure that was already criticized by economists as unrealistic." It should be noted that this amount includes 500 billion zlotys from anticipated European Union funds, expected loans from international institutions, and an infusion of private investments. (Financial Times, 2016).

In addition, Minister Morawiecki has been urging the creation of a "new spirit of Polish entrepreneurship" with an emphasis on fostering opportunities in economic sectors (both goods and services) that would be export sensitive, the creation of new Polish brands ("Polish Champions") which could compete worldwide with high-quality recognizable products, and which would assure the return of many of Poland's "best and brightest" who had emigrated in the search of economic opportunity in Western Europe, the United Kingdom, and the United States. (Strybel, 2017).

In order to facilitate private entrepreneurship, Morawiecki has promised to slash red tape and other bureaucratic interference with creating Polish businesses (Poland ranks $24^{\text {th }}$ in the World Bank's "doing business" survey (World Bank, 2016)—surprisingly with Krakow, Warsaw, and Gdansk at the bottom of the list), reduce waiting period for registrations of new businesses, streamline licensing and permit requirements, and reduce unnecessary government inspections that slow down the opening of business operations. 
The Morawiecki Plan has been termed Polonization (or re-Polonization) which will include buying back businesses previously privatized. However, where the funds will come from to accomplish this objective remains to be seen. Poland is still a country that "lacks capital," although no longer "capitalists." A policy announced by the government under which a tax on large, mainly foreign-owned retail chains and banks has been questioned by the European Union. (Martewicz \& Krasuski, 2016; Foy, 2016). The tax on banks not meeting its expected target of 5.5 billion zl. and instead was projected to raise only 3 billion zl. in revenue. The tax on large retailers was questioned on grounds that it amounted to "unacceptable state aid for small [Polish enterprises" and had to be shelved until 2018. (Zygulski, 2016/2017).

\section{SOME BRIEF CONCLUDING COMMENTS}

In 2014, Bloomberg.com had named Poland the "best country" in Eastern Europe and Central Asia with which to do business. (Bloomberg, 2014; Skolimowski, 2014). Just a year later, the election results for both the Presidency (BBC.com, 2015) and the Parliament (Sejm), which resulted in a fundamental change in both policy and tactics, were not viewed with unanimous approval either within Poland (Reuters, 2016) or within the broader European Union. Many have concluded that the sixth largest economy in Europe is now faced with major challenges posed within its own borders.

Since the conservative, religious, right-oriented political party PiS came to power in the fall of 2015, many believe that Poland has slowly begun transitioning from Europe's "poster child" of success of post-communist nations to Europe's potential "problem child." (Hunter \& Domanska, 2016). The political changes that the new government has undertaken during its short time in office have shaken the confidence of many foreign investors. Critics cite proposals to limit rights of free assembly; attempts to pass legislation banning abortion under almost any circumstances and criminalizing abortions by providing for prison sentences for women who decide to terminate "non-threatening pregnancies (but is likely to "come up with other anti-abortion initiatives under pressure from the country's powerful Roman Catholic Church (Zygulski, 2016/2017)); limiting press access (Day, 2016) while disallowing video and sound recording on the premises of the Parliament; enacting a new media law (BBC.com, 2016a); and replacing judges on Poland's Constitutional Tribunal (BBC.com, 2016b; Business Recorder, 2016), creating a constitutional crisis (RT International, 2015) and "setting the party on a collision course with EU institutions and the human rights body, the Council of Europe, specifically the advisory panel known as the Vienna Commission." (Zygulski, 2016/2017).

Although unrelated to economic policy in the strictest sense, critics of the current regime fear that Poland may have gone too far in "looking inward" and to discouraging the kind of foreign participation in its economy that at least seemed to have achieved much in the past quarter century. (E.g., Casillas, 2016). They point to several undelivered promises on the part of PiS, including failure to raise the tax-free threshold for the Personal Income Tax or PIT; failure to lower the retirement age, and failure to convert Swiss franc-denominated mortgages into zlotys. (Zygulski, 2016/2017).

Not all are alarmed by recent events in Poland. (Cienski, 2016). There is a strong element of public opinion that sees these actions as essentially restoring Poland's sovereignty over its own economy and establishing the authority of the Polish state over its economic future. And PiS continues to hold the first place among Polish political parties in terms of electoral support-"reaching 40\% in some surveys." (Zygulski, 2016/2017).

Which view is correct? Only time will tell! 


\section{Works Cited}

Balcerowicz, Leszek. (1995). Socialism, Capitalism, Transformation. New York: Central European Press.

BBC.com. (2015). President Komorowski Loses to Rival Duda, Bbc.com [BBC News]. [Online] Available: http://www.bbc.com/news/world-europe-32862772 (May 25, 2015).

BBC.com (2016a). Media Laws: Government Takes Control of State Media. Bbc.com [BBC News]. [Online] Available: http://www.bbc.com/news/world-europe-35257105 (January 7, 2016).

BBC.com. (2016b). Poland's Constitutional Court Clashes with New Government, Bbc.com [BBC News]. [Online] Available: http://www.bbc.com/news/world-europe-35766482 (March 9, 2016).

Bloomberg.com. (2014). Poland Ranked Best for Business in East Europe and Central Asia. [Online] Available: http://www.bloomberg.com/news/articles/2014-01-21/poland-ranked-best-for-business-in-east-europe-and-central-asia (January 24, 2014).

BMI Research. (2017), Poland Infrastructure Report - Q1 2017. [Online]. Available: http://www.bmiresearch.com.

Borowski, Jakub \& Jaworski, Krystian. (2016). Morawiecki Plan Calls For Robust Local

Government Investment. [Online] Available: http://www.financialobserver.eu/wp (June 4, 2016).

Burrell, Kathy. (2009/2016). Polish Migration to the UK in the "New” European Union. London: Routledge.

Business Anti-Corruption.com. (2016). Poland Country Profile: Business Corruption in Poland. [Online] Available: http://www.business-anti-corruption.com/country-profiles/europe-central-asia/poland/snapshot.aspx.

Business Recorder. (2016). Poland's Constitutional Crisis Is Credit Negative: Moody's. [Online] Available: http://www.brecorder.com/world/global-business-a-economy/288614-polands-constitutional-crisis-is-credit-negativemoodys.html (April 4, 2016).

Casillas, Anthony. (2016). Economic Challenges Poland Faces in 2016, Investopedia [Online] Available: http://www.investopedia.com/articles/investing/011416/3/economic-challenges-poland-faces-in-2016.asp (May 1, 2016).

Cienski, Jan. (2016). Poland's PiS Warns Critics: We're Not Changing, Get Used to It, Politico.eu.com. [Online] Available: http://www.politico.eu/article/jaroslaw-kaczynski-constitutional-tribunal-polands-pis-warns-critics-were-notchanging-get-used-to-it/ (May 2, 2016).

Connectusfund. (2015). 17 Big Advantages and Disadvantages of Foreign Direct Investment, Connectus. [Online] Available: http://connectusfund.org/17-big-advantages-and-disadvantages-of-foreign-direct-investment (July $23,2015)$.

Day, Matthew. (2016). Poland's President Signs Controversial New Media Law, The Telegraph. [Online] Available: http://www.telegraph.co.uk/news/worldnews/europe/poland/12088295/Polands-president-signs-controversial-newmedia-law.html (January 7, 2016).

Dougherty. Michael B. (2016). Poland Is Not Descending into Tyranny. It's Just Defying the EU, The Week. [Online]. Available: http://thewekk.com.artickes/669439 (December 27, 2016).

FocusEconomics. (2016). Poland Economic Outlook. [Online] Available: http://www.focuseconomics.com/countries/poland (November 29, 2016).

Foy, Henry. (2015). Duda Presidential Victory Stuns Poland, FT.com [Financial Times]. [Online]. Available: http://www.ft.com/cms/s/0/b72a065a-02d4-11e5-8333-00144feabdc0.html (May 5, 2015).

Foy, Henry. (2016). Foreign Companies to Lose Polish Tax 'privilege, FT.com [Financial Times]. [Online] Available: http://www.ft.com/intl/cms/s/0/ed539b74-cc19-11e5-be0b-b7ece4e953a0.html\#axzz47SnzgaMn (February 7, 2016).

Foy, Henry. (2016). Poland Vows to End Free Market Approach Despite Gains, FT.com

[Financial Times] [Online] Available: http://www.ft.com/content/6a702384-2e49-11e6-bf8d-26294ad519fc (June 9, 2016)

Garland, Eric. (2015). Reflections on the Balcerowicz Plan. Problems of European Economics: 21: 227-244. 
Heimann, Beata. (2001). Tax Incentives for Foreign Investment in the Tax Systems of Poland, the Netherlands, Belgium and France. Institute for World Economics and International Management, University of Bremen.

Heywood, Paul \& Meyer-Sahling, Jan-Hinrik. (2013). Danger Zones of Corruption: HowManagement of Ministerial Bureaucracy Affects Corruption Risks in Poland. Public Administration and Development, 33(3): 191-204.

Hunter, Richard J. Jr. \& Domanska, Marta. (2016). Poland: A Country Study-“Europe’s Poster Child to Europe’s Problem Child." Issues in Economics and Business, 2(1): 15-27.

Hunter, Richard J., Jr. \& Mest, David. (2015). An Update on Major Enforcement Actions: Under the Accounting Provisions of the Foreign Corrupt Practices Act or FCPA. International Journal of Management Sciences, 6(4): 176186.

Hunter, Richard J. Jr., Nowak, Artur \& Ryan, Leo V., C.S.V. (1995). Legal Aspects of the Transformation Process in Poland: Business Association Forms. The Polish Review, 40(4): 387-407.

Hunter, Richard J., Jr. \& Ryan, Leo V. C.S.V. (1998). From Autarchy to Market: Polish Economics and Politics, 19451989. Westport, Conn.: Praeger.

Hunter, Richard J. Jr. \& Ryan, Leo V., C.S.V. (2006). Transition in the Polish Economy, in Developmental Entrepreneurship: Adversity, Risk, and Isolation (Craig S. Galbraith \& Curt H. Stiles eds., San Diego: Elsevier): 71-87.

Hunter, Richard J., Jr. \& Ryan, Leo V., C.S.V. (2008). The Ten Most Important Economic and Political Events Since the Onset of the Transition in Post-Communist Poland. The Polish Review, 53(2): 183-216.

Hunter, Richard J., Jr. \& Ryan, Leo V., C.S.V. (2009). Poland in 1989: Enter Tadeusz Mazowiecki and the Creation of the Balcerowicz Plan. Research Journal of International Studies, Issue 11, Art. 4.

Hunter, Richard J., Jr. \& Ryan, Leo V., C.S.V. (2013). Economic Transformation and Privatization. Warsaw East European Review, 3: 37-52.

Jermakowicz, Wladyslaw. (2001). Foreign Investment in Poland, in Foreign Investment and Privatization Eastern Europe (Patrick Artisien-Maksimenko \& Matjia Rojec eds., London: Palgrave MacMillan): 156-173.

Jasiniak, Magdalena. (2015). Is Poland Still Attractive for Foreign Investments? Financial Internet Quarterly, 11(2): 10-17.

Johnson, Simon \& Loveman, Gary W. (1995). Starting Over: Poland After Communism. Harvard Business Review. [Online] Available: https://hbr.org/1995/03/starting-over-poland-after-communism (March-April 1995).

Kaminski, Bartolomiej. (1991). The Collapse of State Socialism: The Case of Poland. Princeton, N.J.: Princeton University Press.

Martewicz, Maciej \& Krasuski, Konrad. (2016). Poland Takes Aim at Retailers With \$485 Million Tax Plan, Bloomberg.com. [Online] Available: http://www.bloomberg.com/news/articles/2016-01-25/poland-to-help-localshops-as-new-tax-targets-bigger-retailers (January 25, 2016).

Murrell, Peter. (2013). What is Shock Therapy? What Did it Do in Poland and Russia? Post Soviet Affairs, 9(2): 111140.

OECD [Organization for Economic Cooperation and Development]. (2014). Statistical Extracts. [Online] Available: http://stats.oecd.org/.

Orenstein, Mitchell A. (2014). From Tragedy to Triumph. Foreign Affairs, 93(1): 23-27.

PAIiIZ [Polish Information and Foreign Investment Agency]. (2016). Invest in Poland (Sectors). [Online] Available: http://www.paiz.gov.pl/sectors\#.

Reuters. (2016). Thousands March in Anti-government Protest in Poland, Reuters. [Online] Available: http://www.sbs.com.au/news/article/2016/05/08/thousands-march-anti-government-protest-poland (May 8, 2016).

RT International. (2015). Poland Enacts 'crippling' Constitutional Court Law despite EU Indignation, Rt.com. [Online] Available: https://www.rt.com/news/327240-poland-constitutional-court-law/ (December 28, 2015).

Sachs, Jeffrey. (1993a). Poland's Jump to a Market Economy. Cambridge, Mass.: MIT Press.

Sachs, Jeffrey. (1993b). The Economic Transformation of Eastern Europe: The Case of Poland. Economics of Planning, 25(1): 5-19. 
Hunter, R. J. (2017). Charting a New Path for Poland or Turning Its Back On More Than a Quarter Century of Progress? Archives of Business Research, 5(2), 20-30

Santandertrade.com. (2016). Foreign Investment in Poland. [Online] Available: https://en.portal.santandertrade.com.establish-overseas/poland/foreigninvestment.

Sarmatian Review. (2017). Sarmatian Review Data: The Flip Side of Foreign Investment in Poland, 2050 (January 2017).

Skolimowski, Piotr. (2014). Poland Ranked Best for Business in East Europe and Central Asia, Bloomberg.com [Bloomberg]. [Online] Available: http://www.bloomberg.com/news/articles/2014-01-21/poland-ranked-best-forbusiness-in-east-europe-and-central-asia (January 21, 2014).

Stanley, Bill. (2015). Andrzej Duda: Spotlight on Poland's New President, Notes from Poland. [Online] Available: https://notesfrompoland.com/2015/08/26/andrzej-duda-spotlight-on-polands-new-president/ (August 26, 2015).

Strybel, Robert. (2017). Can the Morawiecki Plan Revitalize Poland's Economy? Polish American Journal, 2 (January 2017).

Trading Economics. (2016). Poland Unemployment Rate 1990-2016,

Tradingeconomics.com [Trading Economics]. [Online] Available: http://www.tradingeconomics.com/poland/unemployment-rate.

Transparency International. (2016). Corruption by Country (Poland). [Online] Available:

https://www.transparency.org/country/\#POL.

United States Department of State. (2013). 2013 Investment Climate Statement - Poland, State.gov. [Online] Available: http://www.state.gov/e/eb/rls/othr/ics/2013/204716.htm.

United States Department of State. (2015). 2015 Investment Climate Statement - Poland, State.gov. [Online] Available: http://www.state.gov/e/eb/rls/othr/ics/2015/241708.htm.

World Bank. (2017). Doing Business: Economy Ranking. Available: http://www.worldbank.org/.

Zygulski, Witold. (2016/2017). Poland's Conservative Government One Year On, The Warsaw Voice, 6-7 (Winter).

Please Note: The outline of this paper was jointly prepared by Professor Hunter and the late Brother Leo V. Ryan, C.S.V., who died in June of 2016. This paper is dedicated to this extraordinary educator, dean, and scholar. + 